\title{
COMPARATIVE EVALUATION OF NON-MOTOR DISPLAYS OF THE PARKINSON'S DISEASE AND VASCULAR PARKINSONISM
}

\author{
Khalimova Kh.M. ${ }^{2},{ }^{*}$ Raimova M.M. ${ }^{1}$, Matmurodov R.J. ${ }^{2}$, Abdullayeva M.B. ${ }^{1}$, Ergashev U. ${ }^{2}$, Halimmatova M. ${ }^{2}$ \\ ${ }^{1}$ Tashkent State Dental Institute, Tashkent, Uzbekistan; \\ ${ }^{2}$ Tashkent Medical Academy, Tashkent, Uzbekistan
}

The purpose of the research: To conduct a comparative analysis of the frequency and nature of the non-motor manifestations of Parkinson's disease (PD) and vascular parkinsonism (VP).

Material and Methods. The research was carried out in 153 patients with Parkinson's disease (PD) and 69 patients with vascular parkinsonism (VP). Clinical and neurological studies, assessment of the severity of emotional disorders using $g$ scale HADS, cognitive function was examined by the scale MMSE.

Results. Autonomic disturbances were observed in 2.5 times more likely in patients with PD and $85 \%$ in patients with VP, they were observed by us in $30 \%$ of patients. Among autonomic dysfunctions in patients with PD, the most frequently observed general hyperhidrosis, voiding, and constipation... In patients with VP autonomic disorders occurred less often than patients with PD, however, the severity and frequency of occurrence of orthostatic hypotension was higher in VP compared with PD. Among emotional disorders in PD one of the most frequent was a depressive syndrome. It was observed in $58.8 \%$ of patients, while in the group with vascular parkinsonism its frequency was $30.4 \%$. Level of depression of HADS in PD was statistically higher than VP patients. Cognitive impairment developed in both groups, approximately at the same percentage of cases; however, the degree of cognitive impairment was higher in the group of patients with VP.

Keywords: Parkinson's disease, vascular parkinsonism, non-motor symptoms.

In the past, vascular brain damage was considered the main cause of parkinsonism, but now this view is refuted, as pathological studies show that it accounts for only 3-8\% of cases of parkinsonism $[1,2,6,8,13,15,20,21]$. According to V.L. Golubev, Y.I. Levin and A.M. Wayn (1999), vascular parkinsonism (VP) is found only in $6 \%$, and according to Yebiger (1986) - 7.7\% of all other forms of parkinsonism. The true prevalence of the joint venture can be determined only through clinical and epidemiological researches $[16,17,18$, 19]. C.Trenkwalder et al. (1995), conducted a population-based study of the inhabitants of Bavaria over 65 years, parkinsonism found in 24 of 982 surveyed, with vascular parkinsonism was detected in only 2 patients, which accounted for $0.2 \%$ of all those surveyed, or $8 \%$ of the total number of patients with parkinsonism.

Differential diagnosis of Parkinson's disease and vascular parkinsonism associated with certain difficulties due to the similarity of the clinical picture, the possibility of a combination of neurodegenerative and vascular mechanisms of the disease. Need to clarify the clinical and instrumental diagnostic criteria for these conditions [19, 21, 22, 23]. Parkinson's disease has traditionally been viewed as a disease mainly affecting the scope of the motor. But, in addition to motor symptoms in the clinical picture of Parkinson's *e-mail: malikamed-74@yandex.ru disease and non-motor manifestations are present [20]. Moreover, as the disease progresses, some of them become dominant clinical significance, having a negative impact on the quality of life of patients, leading to their disability and reducing life expectancy. Currently, one of the most pressing areas of study developed parkinsonism is to further study the impact of non-motor disorders and approaches to their therapy on quality of life, among them a lot of attention paid to the vegetative, emotional, cognitive disorders.

Objective. To conduct a comparative analysis of the frequency and nature of the non-motor manifestations of Parkinson's disease and vascular parkinsonism.

Material and Methods. The research was carried out on a sample of 222 patients with parkinsonism, 153 patients with Parkinson's disease and 69 patients with vascular parkinsonism. Clinicalneurological research included: studies of somatic and neurological status, laboratory tests (clinical and biochemical), CT scan or MRI of the brain.

Nosological parkinsonism diagnosis was carried out using clinical brain bank diagnostic criteria for Parkinson's Disease Society UK "(AJ Hughes et al., 1992), differentiated where necessary by using structural imaging techniques (CT, MRI). Evaluation of the severity of neurological deficit was performed using standardized rating scale evaluation manifes- 
tations of Parkinson's disease (UPDRS, Fahn S., Elton R., 1987), the stage of disease was determined by the scale-hyun and Yara (M. Hoehn, M. Yahr, 1967) in the modification and Lindval et al. (1989).

On the prevalence of the clinical picture of a symptom isolated 3 basic forms BP: mixed (in which equally represented hypokinesia, rigidity and tremor), akinetic-rigidity (hypokinesia and rigidity) and trembling (tremor predominates, with a small representation of hypokinesia and rigidity). Quality of life scales were studied using the Schwab and England to assess activities of daily living. To assess the degree of emotional disorders in patients with Parkinson's used hospital anxiety and depression scale (HADS). The general condition of the cognitive functions was examined by Mini-mental state examination (Mini-Mental State Examination - MMSE) [Folstein MF, Folstein SF et al., 1975]

Comparison of the clinical picture of Parkinson's disease in subgroups was carried out on the following parameters: gender, patient specific forms of the disease: akinetic-rigid, trembling, mixed; disease stage (I, II, III, IV stage scale Hoehn \& Yahr) mean age of patients, average age of onset of the disease, a positive family history, and having a positive effect in treating the side effects-L-Dopa containing preparations. The last two parameters were evaluated only in the part of the patients who received drugs containing L-DOPA.

Results. Autonomic disturbances observed 2.5 times more frequently in patients with PD and were $85 \%$, whereas patients with VP, they were observed in $30 \%$ of patients. Among autonomic dysfunctions in patients with PD, the most frequently observed general hyperhydrosis $(78.4 \%)$, urinary disorders $(71.9 \%)$, constipation $(52.3 \%)$, drooling $(45.7 \%)$ (Tab.1) In patients with SP general hyperhidrosis was observed in $5.8 \%$ of cases, urination disorders in $20.3 \%, 10.1 \%$ constipation, salivating at $8.7 \%$, which is significantly less, respectively, than in patients with PD. However, the severity and incidence of orthostatic hypotension was higher when VP compared with PD (26.1\% and $12.4 \%)$, which is apparently due to the initial dysfunction cardiovascular system in vascular parkinsonism (Fig.1).

\section{Frequency of major non-motor manifestations of PD and VP}

\begin{tabular}{|c|c|c|c|}
\hline Sign & $\begin{array}{l}\text { Parkinson's disease } \\
\qquad(\mathrm{n}=153)\end{array}$ & $\begin{array}{c}\text { Vascular } \\
\text { parkinsonism } \\
\qquad(n=69)\end{array}$ & Total \\
\hline Violations of smell & $135(88,2 \%)$ & $20(28,9 \%)^{*}$ & $155(69,8 \%)$ \\
\hline Autonomic disorders & $130(85 \%)$ & $20(30 \%)^{*}$ & $150(67,6 \%)$ \\
\hline orthostatic hypotension & $19(12,4 \%)$ & $18(26,1 \%)$ & $37(16,7 \%)$ \\
\hline salivation & $70(45,7 \%)$ & $6(8,7 \%)^{*}$ & $76(34,2 \%)$ \\
\hline constipation & $80(52,3 \%)$ & $7(10,1 \%)^{*}$ & $87(39,2 \%)$ \\
\hline urination disorders & $110(71,9 \%)$ & $14(20,3 \%)^{*}$ & $124(55,8 \%)$ \\
\hline total hyperhidrosis & $120(78,4 \%)$ & $4(5,8 \%)^{*}$ & $124(55,8 \%)$ \\
\hline Emotional disturbances & $120(78,4 \%)$ & $30(43,5 \%)$ & $150(67,6 \%)$ \\
\hline Depression & $90(58,8 \%)$ & $21(30,4 \%)^{*}$ & $111(50 \%)$ \\
\hline Anxiety & $40(26,1 \%)$ & $12(17,4 \%)$ & $52(23,4 \%)$ \\
\hline Cognitive impairment & $130(84,9 \%)$ & $60(86,9 \%)$ & $190(85,6 \%)$ \\
\hline Positive response to & $\mathrm{n}=102$ & $\mathrm{n}=38$ & $\mathrm{n}=140$ \\
\hline levodopaterapy & $89(87,2 \%)$ & $15(39,5 \%)^{*}$ & $104(74,3 \%)$ \\
\hline Medicinal dyskinesia & $40(39,2 \%)$ & $20(52,6 \%)$ & $60(42,8 \%)$ \\
\hline
\end{tabular}

Note: * -reliable differences between treatment groups at $\mathbf{p}<0.05$ 


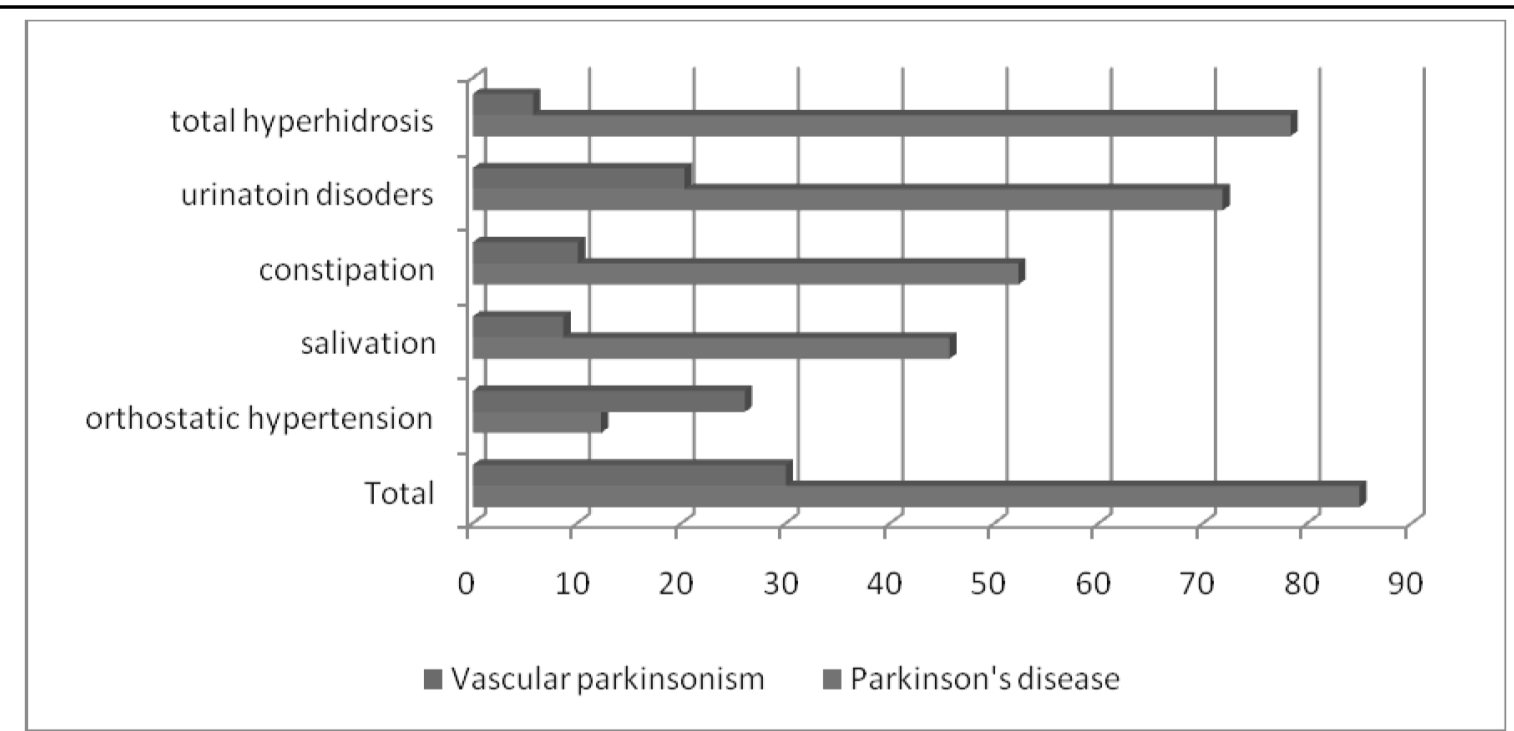

Figure 1. Frequency of occurrence of autonomic disorders in Parkinson's disease and vascular parkinsonism.

Affective disorders include depression, anxi- 30.4\%, that's almost 2 times less. Analysis of anxety, apathy, obsessive-compulsive syndrome. iety and depressive symptoms using the rating One of the most common and clinically signifi- scale hospital anxiety and depression (HADS) in cant affective disorders in parkinsonism is depression [11]. The presence of depression is the factor most closely paired with low quality of life of patients. The leading symptoms of depression in PD is a feeling of emptiness and hopelessness, decreased reactivity to emotional stimuli, limiting opportunities to experience joy and have fun (anhedonia).

In our study, among the emotional disorders in PD one of the most frequent was a depressive syndrome. In varying degrees of severity, he was seen in $58.8 \%$ of patients, whereas in the group with vascular parkinsonism its frequency was patients with PD and VP revealed that the level of depression on the scale of HADS in PD was statistically higher than in the VP $(p<0,001)$. Among patients with PD 1.7 times more likely recorded subclinical depression severity $(24.8 \%)$ and 2.1 times - clinical depression (34\%) compared to patients with VP $(14.5 \%$ and $15.9 \%$, respectively) $(\mathrm{p}<0.001)$. Those without depression in PD group was 1.7 times less than in the group with the joint venture. The degree of severity and frequency of occurrence of the alarm did not reach statistically significant differences in both analyzed groups $(\mathrm{P}<0.2)$ (Fig. 2.)

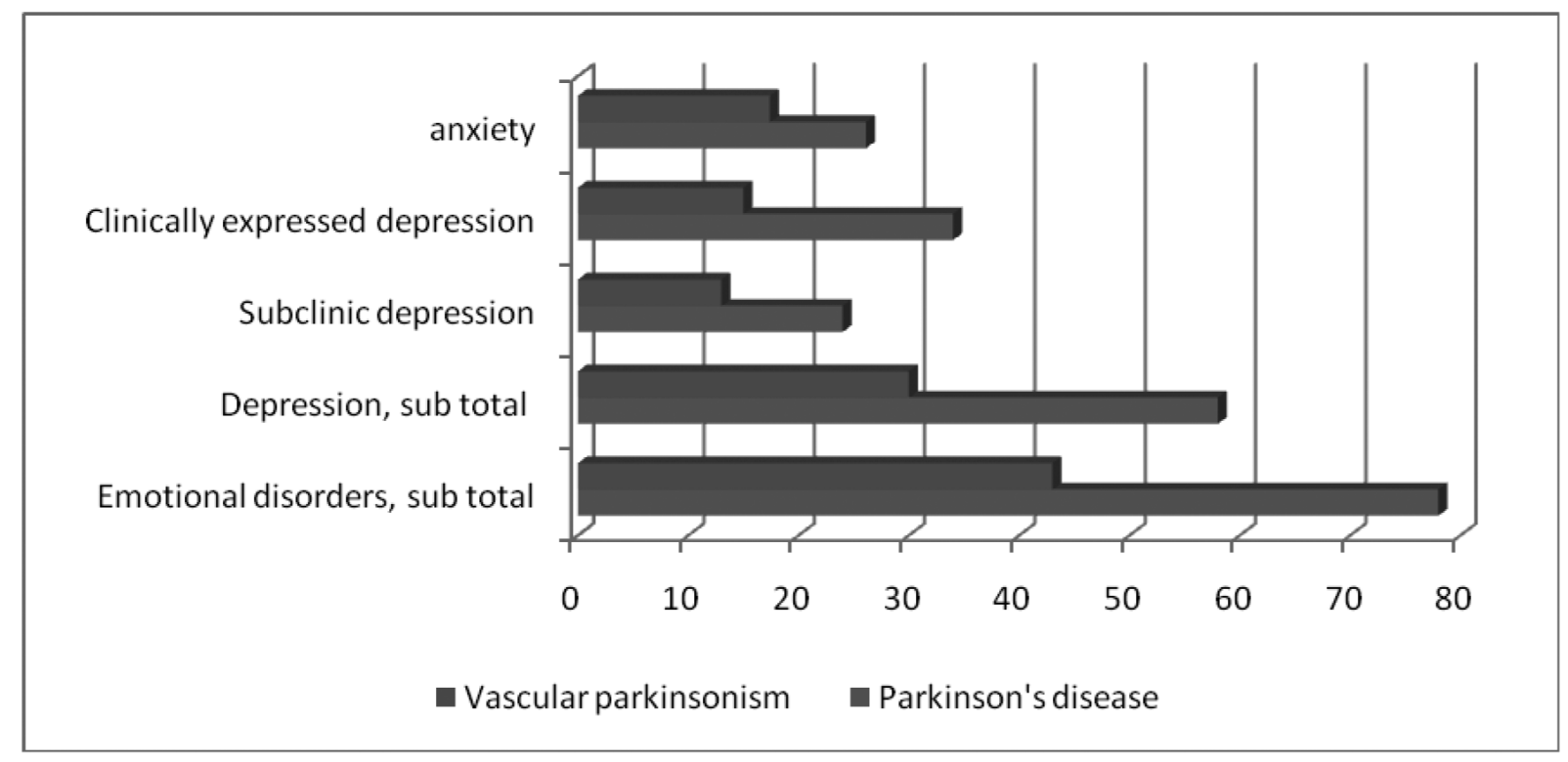

Figure 2. The incidence of mood disorders in Parkinson's disease and vascular parkinsonism 
When considering the cognitive functions in patients examined it was found that cognitive impairment developed in both groups, approximately the same percentage of cases $(84.9 \%$ and $86.9 \%$ - BP - VP), but the degree of cognitive impairment was higher in the group of patients with VP. This was reflected in lower total values on the MMSE in patients with vascular parkinsonism $(22.7 \pm 1.2)$ compared with PD $(25.9 \pm 0.7 \%$, $\mathrm{p}<0,05)$, indicating a more pronounced changes intellectually and memory functions. Patients with PD was dominated mainly by the type of violation lesions of subcortical structures with a slowing of thought processes, impaired delayed recall information: disregulatory and neurodynamic disorders, lack of visual-spatial functions and nominative function of speech. In patients with VP observed elements of speech and dispractical disorders, speech difficulties in forming associations, indicating involvement in the pathological process as subcortical and cortical structures.

Very important in differential diagnostic point of view diagnostic criteria for PD is a positive response to levodopaterapy. Traditionally, levodopa ineffective at VP, but in recent years it became clear that even in the cases the pathologically proven resistant positive response to levodopa, especially in those cases where the vascular lesions involve the nigrostriatal pathway (either at a black substance, or at the level striatum). Moreover, in some patients on long-term use of levodopa background develop dyskinesias and fluctuations. In our research group with the VP in $39.5 \%$ of cases there is a positive response to levodopaterapy, against $87.2 \%$ in the group with PD, but this effect in most cases, had a short duration and in 20 cases $(52.6 \%)$ was characterized by development of drug dyskinesias for $18 \pm 8$ months. When a positive response to the levodopaterapy PD was more pronounced, however, as well as in the group with the VP developed drugs dyskinesia in 40 cases $(39.2 \%)$, but in a more remote period, after $38 \pm 14$ months. As you know, in the development of vascular parkinsonism play an important role cerebrovascular diseases such as cerebral atherosclerosis, hypertension and others. Analysis of previous or background and concomitant diseases: hyperten- sion, diabetes, coronary heart disease, cerebral arteriosclerosis and et al. showed that the joint venture is often $(84 \%)$ combined with visceral (HID, the combination of hypertension and type 2 diabetes). Among these diseases is a strong correlation was found between the severity of the joint venture and the degree of atherosclerotic vascular lesions $(\mathrm{r}=0.6)$, systolic blood pressure $(r=0.78)$, blood glucose level $(r=0.67)$.

As an example, we give the following observation:

Patient M., born in 1946, entered with complaints of general stiffness, slowness of movement, difficulty in chewing, swallowing, constipation, difficulty speaking, frequent urination, excessive salivation, weight loss, blood pressure fluctuations.

Medical history: He considers himself sick for 5 years. The disease began with stiffness in his hands. Progressing gradually spread to the legs. Joined by a change of gait, with small steps, instability. Suffers from diabetes for 7 years, the level of glucose maintained hypoglycemic drugs irregularly, increased blood pressure for 6 years, antihypertensive drugs has also been irregular. Received repeated treatment, however, the disease progresses steadily, joined speech difficulties, drooling, there have been cases of hardening, falls due to instability.

Life history: the profession-driver, served for four years in Afghanistan, a car accident injury of the chest, without head injury, multiple stressful situations.

Family history: burdened by hypertension, the mother of the patient was observed hypertension

Objective: The general condition of moderate severity. The skin cover is clean. Lymph nodes were not enlarged. Deformation of the chest, in the region of the sternum, post-traumatic etiology. In the lungs, vesicular breathing. Heart sounds are muffled, accent II tone of the aorta, pulse 70 stroke in min. Blood pressure of 130/80 $\mathrm{mm}$. m.c. Tongue is moist, coated with white bloom. Abdominal palpation soft, paimless. The liver and spleen were not palpable. Patients concerned about constipation. Pasternatskiy's sign $(-)$, frequent urination, edema is not. 
Neurological status: The movement of the eyeballs in full. The weakness of convergence on both sides. No nystagmus. Gipomimiya. Central paresis VII pair of left cranial nerv. Reducing swallowing reflex on the left. Dysphagia. Dysphonia. Paresis and paralysis did not appear. Marked hypokinesia in the extremities, $\mathrm{L}=\mathrm{R}$. Increased muscle tone in all the limbs on the type of plastic, $\mathrm{L}=\mathrm{R}$. Symptom gear in both elbow and wrist joints $\mathrm{L}=\mathrm{R}$. Statokinetic tremor observed in both hands, the left leg. Gait bent back, 2 sides aheyrokinezis, anteropulsiya, postural instability. The tendon reflexes were reduced from BR-TR, with PR-AR L $>$ R. In the Romberg position is stable. Coordination tests performs with ataxia on both sides, L $>$ R. Marinesku-Rodovich's symptom (+) on both sides, left Babinskiy pathological symptom. Notes hypersalivation. The patient emotionally labile, there is an involuntary cry. Cognitive function -MMSE-22 points, clock drawing test5 points (mild dementia).

These laboratory and instrumental investigations:

Blood tests: Hemoglobin -134, er-4.2, CI-0.9, leukocytes - 6.4; segments -64, lymphocytes-29, monocytes-5, SSE-30

Biochemistry analysis of blood: AST -0.22, ALT 0.44 , , total biluribin $-19.44 \mathrm{mg} \%$, straight 4.86 ; is not straight $-14.58 \mathrm{mg}^{0} \%$; urea-7.1, creatinine - 159.1

Sugar of blood: 24.02.2009-4.8; 2.03.2009-4,8

Coagulation Time of recalcification -1 25, PTI-100\% Fibrinogen A 3.3 -tolerance to geparine - 9 20; trombotest - V, fibrinolytic activity $-9.26 \%$, the ethanol test - Neg, retraction $63 \%$, the index of retraction of -0.4 , hematocritis $-36 \%$.

Analysis of urine: specific weight - 1009, protein - abs, leukocytes 2-6, oxalates, bacteria +

Ultrasound inv.: Chronic prostatitis.

ECG: Moderate Left type ECG.

REG: CB (FM) blood flow deficiency $L>R$ due to lower the tone of the vascular wall, vascular wall rigidity, venous discirculation.

MRI of the brain: In the white matter of the brain, multiple hyperintense lesions, measuring 1-2 $\mathrm{mm}$ in diameter, localized predominantly periventricular. Convexital subarachnoid and perivascular spaces expanded. Differentiation in the gray and white matter is reduced. The lateral ventricles of the brain moderately expanded presence leycoareozis.

Ultrasound duplex scanning of aortic arch branches: the lumen of the right common carotid artery stenosis at the bifurcation by $10 \%$ due to the flat "fibrous" plaque, excessive branching, moderate, turbulent blood flow lumen of the left common carotid artery stenosis at the bifurcation by $15 \%$ due to flat "fibrous" plaques, excessive branching, moderate, turbulent blood flow. The right and left internal carotid artery lumenfree, blood flow is sufficient. Right vertebral artery blood flow, reduced-79ml MRI of the brain: In the white matter of the brain, multiple hyperintense lesions, measuring 1-2 $\mathrm{mm}$ in diameter, localized predominantly periventricular. Convexital subarachnoid and perivascular spaces expanded. Differentiation in the gray and white matter is reduced. The lateral ventricles of the brain moderately expanded presence leyroareozis.

Therapist: Chronic spastic colitis.

Endocrinologist: Diabetes mellitus type II, severe course.

Urologist: Chronic prostatitis,

Proctologist: .. Internal and external hemorrhoids, chronic colostasis.

Clinical diagnosis: Chronic cerebral ischemia stage II, essential hypertension stage II and cerebral arteriosclerosis with vascular parkinsonism syndrome, mixed form, III stage by Hehn and Yahr.

Related diagnosed: diabetes mellitus type II, severe course. Chronic spastic colitis. Chronic prostatitis. Internal and external hemorrhoids, chronic colostasis.

Complications: Diabetic polyneuropathy IIIst. Diabetic encephalopathy.

Treatment: Cavinton 2.0 per nat solution in $/ \mathrm{v}$, drip, Riboksin 10.0 in/vin, Vit B6 5\%-6.0 in/v in the nat. solution, Nicotinic acid 1\%- $2.0 \mathrm{in} / \mathrm{m}$, Piracetam 10.0 in/v, Thrombo-ACC 1 tabl., Borboval 10 drops 2 times a day, Berlitioni 600ED on nat solution in/v, drip, Piracetam $20 \%$ 10.0 in/v., Madopar 125 1kaps to 4 times a day, 
Tebantin 1kaps 1/d, Tadenan $50 \mathrm{mg}$ 2/d, Zakson $2 \mathrm{mg}$ 1/night. Physiotherapy.

During treatment the patient's condition improves, there is an improvement of gait, the patient begins to walk without support, not observed a fall, pour point, improved speech, decreased salivation.

Analysis of the clinical case illustrates the typical features of vascular parkinsonism, such as the onset of the disease on the background of hypertension, diabetes mellitus, are not subject to adequate correction of blood pressure and blood glucose levels. Subacute onset, rapidly progressive (development of III-stage gravityHoehn and Yahr within 5 years), with the rapid development of postural instability. The presence of characteristic of vascular lesions of the brain changes on MRI and ultrasound duplex scanning of aortic arch branches, as well as some improvement on the background of ongoing metabolic, vascular, and antiparkinsonian therapy.

Conclusion. In summary description of the results of the research, the following conclusions:

1. Parkinson's disease and vascular parkinson-

\section{REFERENCES}

1. Artemyev D.V., Yahno N.N.: Etiology and pathogenesis of Parkinson's disease. Rus.med. journal. 2001; 9: 4-9.

2. Baytimerov A.R. Epidemiological, clinical and genetic study of Parkinson's disease in the Republic of Bashkortostan. Authoref. of dis. phd. Ufa. 2007: 22.

3. Batukaeva L.A. Dynamics of motor and cognitive impairment in Parkinson's disease. Authoref. of dis. phd. Moscow. 2010: 24.

4. Boiko A.N., Petrov S.V. Register of patients with Parkinson's disease. Motion sickness: medical and social aspects. Moscow. 2010: 297-302.

5. Gashilova F.F. Zhukova N.G., Bezlyak V. Cognitive impairment in patients with Parkinson's disease. Doctor. 2006; 8: 55-57.

6. Golubev V.L. Levin Ya., Vein A.M. Parkinson's disease and Parkinson's syndrome. - M .: Med. Press. 1999: 415 p.

7. Gusev E.I., Geht A.B., Popov G.R. et al. Quality of life and economic aspects of Parkinson's disease. Motion sickness: medical and social aspects: materials of the International Scientific Conference. Moscow. 2010: 37-41 8. Damulin I.V., Model M. R., Levchenko A.G., Cherdak M.A. Parkinsonism, disbaziya and dementia in patient with circulatory encephalopathy stage III . Neurological journal. 2010; 2: 43-51.

9. Ermakova L.A., Vasilenko A.F., Shamurov Y.S., Ostanina M.A. Comparative analysis of disorders of high- ism are significant differences between them, both in clinical manifestations and in flow characteristics.

2. Autonomic disturbances occur 2.5 times more frequently in PD (85\%) compared with VP $(30 \%)$. Among the most frequently develop a common rash $(78.4 \%)$, urinary disorders (71.9\%), constipation (52.3\%), drooling (45.7\%). However, a higher incidence and severity of orthostatic hypotension observed in the joint venture.

3. Affective disorders (depression and anxiety) were more frequent in PD. Level of depression in PD is statistically higher than in the VP $(p<0.001)$, which manifests itself in more frequent development of clinically significant depression $(34 \%$ and $15.9 \%$, respectively, $\mathrm{p}<0.05$ ).

4. The degree of cognitive disorders was higher in the group with vascular parkinsonism, manifested in a lower total on the MMSE values in patients with vascular parkinsonism $(22.7 \pm 1.2)$ compared with PD $(25.9 \pm 0.7 \% \mathrm{p}<0.05)$, and evidence of more pronounced changes intellectually and memory functions

er mental functions in different types of Parkinson's disease. Ural Medical journal. 2010; 4: 104-111.

10. Jukova I.A. Cognitive impairment in patients with Parkinson's disease. Author. Of diss. phd. Irkutsk; 2010: 25. 11. Jukova I.A., Jukova N.G., Alifirova V.M. Non-motor manifestations of Parkinson's disease. Bulletin of anthrax medicine. 2009; 1 (2): 136-141.

12. Levine OS, Batukaeva LA approaches to therapy of cognitive impairment in Parkinson's disease. Parkinson's disease and movement disorders. Guidelines for doctors on the materials I National Congress (Moscow, September 22-23, 2008; 108-111.

13. Levin O.S., Dokadina L.V. Epidemiology of Parkinson's disease and Parkinson's disease. Neurological journal. 2005; 5: 41-50.

14. Levin O.S., Ivanov A.K., Batukaeva L.A. Makhno S.O. Non-motor manifestations of Parkinson's disease. Russian Medical Journal 2009; 6: 52-56

15. Levin O.S. Vascular parkinsonism. Journal of Neurology, 1997; 4: 42-51.

16. Levine O.S., Fedorova N.V., Shtok V.N. The differential diagnosis of parkinsonism . Journal neurologist. and psihiatr. 2003; 2: 54-60.

17. Stratchunskaya E.Y. Epidemiology of Parkinson's disease Bulletin of the Russian Academy of Natural Sciences. St. Petersburg, 2006; 1: 86-91. 
18. Gelb DJ, Oliver E, Gilman S. Diagnostic criteria for Parkinson's disease.// Arch Neurol.-1999; 56: 33-39.

19. Hughes AJ, Ben Shlomo Y, Daniel SE, et al. What features improve the accuracy of clinical diagnosis in Parkinson's disease: a clinicopathologic study. Neurology.1992; 42: 1142-1146.

20. Katzenschlager R, Zijlmans J, Evans A, Watt H, Lees AJ. Olfactory function distinguishes vascular parkinsonism from Parkinson's disease. J Neurol Neurosurg
Psychiatry. 2004; Vol. 75: 1749-1752.

21. Lees AJ, Hardy J, Revesz T. Parkinson's disease. Lancet. 2009; 373 (9680): 2055-2066.

22. Van Den Eeden SK, Tanner CM, Bernstein AL Incidence of Parkinson's disease: variation by age, gender, and race/ethnicity.// Am J Epidemiol. -2003; 157: 10151022.

23. Ward CD, Gibb WR. Research diagnostic criteria for Parkinson's disease. Adv Neurol 1990; 53: 245-9.

\title{
XÜLASə
}

\section{PARKINSON XəSTOLIYINININ VO DAMAR PARKINSONIZMININ QEYRI-MOTOR ӘLAMӘTLORINIIN MÜQAYISOLI QIYMOTLONDIRILMOSI}

\author{
Xalimova X.M. ${ }^{2}$, Raimova M.M. ${ }^{1}$, Matmurodov R.J. ${ }^{1}$, Abdullayeva M.B. ${ }^{1}$, Erqaşev U. ${ }^{2}$, Xalimmatova M. ${ }^{2}$ \\ ${ }^{1}$ Daşkənd dövlat stomatoloji instituti, Daşkənd, Özbəkistan; \\ ${ }^{2}$ Daşkənd tibb akademiyası, Daşkənd, Özbəkistan
}

Tədqiqatın məqsədi: Parkinson xəstəliyinin (PX) və damar parkinsonizminin (DP) qeyri-hərəki əlamətlərinin xarakterinin və tezliyinin müqayisəli tədqiqi.

Material və metodlar: tədqiqata 153 Parkinson xəstəliyi olan və 69 damar parkinsonizmi olan xəstə calb edilmişdir. Xəstələr klinik-nevroloji müayinədən keçirilmişdir, emosional pozuntuların dərəcəsi HADS şkalası, koqnitiv funksiyaların pozulmasının dərəcəsi MMSE şkalasının köməkliyi ilə qiymətləndirilmişdir.

Nəticələr. Vegetativ pozulmalar PX olanlarda 2,5 dəfə çox rast gəlinmişdir və $85 \%$ təşkil etmişdir. DP zamanı vegetativ pozulmalar 30\% xəstələrdə rast gəlinmişdir. PX olanlarda vegetativ pozulmalar arasında daha çox ümumi hiperhidroz, sidik ifrazının pozulması, qəbizlik müşahidə edilmişdir. DP olanlarda vegetativ pozulmalar daha az inkişaf etmişdir, amma ortostatik hipotenziyanın qabarıqlığı və tezliyi PX nisbətən yüksək olmuşdur. PX zamanı emosional pozulmalar arasında daha çox rast gəlinən depressiv sindrom olmuşdur xəstələrin 58,8\%-də. DP zamanı isə 30,4\% rast gəlinmişdir. HADS şkalası ilə depressiyanın səviyyəsi PX zamanı DP-nə nisbətən statistik yüksək olmuşdur. Koqnitiv pozulmalar hər iki qrupda eyni dərəcədə inkişaf etmişdir, amma koqnitiv pozulmaların qabarıqlıq dərəcəsi DP zamanı yüksək olmuşdur.

Açar sözlər: Parkinson xəstəliyi, damar parkinsonizmi, qeyri-motor simptomlar.

\section{РЕЗЮМЕ}

\section{СРАВНИТЕЛЬНАЯ ОЦЕНКА НЕМОТОРНЫХ ПРОЯВЛЕНИЙ БОЛЕЗНИ ПАРКИНСОНА И СОСУДИСТОГО ПАРКИНСОНИЗМА}

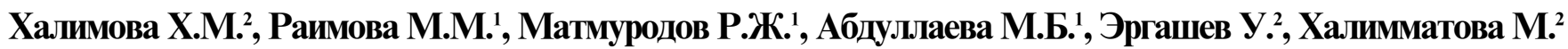 \\ ${ }^{1}$ Ташкентский Государственньй Стоматологический Институт, Ташкент, Узбекистан \\ ${ }^{2}$ Ташкентская Медииинская Академия, Ташкент, Узбекистан
}

Цель исследования: Провести сравнительный анализ частоты и характера недвигательных проявлений болезни Паркинсона (БП) и сосудистого паркинсонизма (СП).

Материал и методы: Исследования проводились у 153 больных с болезнью Паркинсона и у 69 больных с сосудистым паркинсонизмом. Проведены клинико-неврологические исследования; оценка степени выраженности эмоциональных расстройств при помощи шкалы ЩАДС, когнитивные функции исследовали с помощью шкалы ММСЕ. 
Результаты. Вегетативные нарушения наблюдались в 2,5 раза чаще у больных с БП и составляли $85 \%$, у больных с СП они наблюдались нами у $30 \%$ больных. Среди вегетативных нарушений у больных с БП наиболее чаще наблюдались общий гипергидроз, нарушения мочеиспускания, запоры. У больных с СП вегетативные нарушения развивались реже, чем у больных с БП, однако, выраженность и частота встречаемости ортостатической гипотензии была более высокой при СП по сравнению с БП. Среди эмоциональных расстройств при БП одним из наиболее частых был депрессивный синдром. Он отмечался у $58,8 \%$ пациентов, тогда как в группе с сосудистым паркинсонизмом частота его встречаемости составила 30,4\%. Уровень депрессии по шкале ЩАДС при БП был статистически выше, чем при СП. Когнитивные нарушения развивались в обеих группах, примерно в одинаковом проценте случаев, однако степень выраженности когнитивных нарушений была выше в группе больных с СП.

Ключевые слова: Болезнь Паркинсона, сосудистый паркинсонизм, немоторные симптомы.

Redaksiyaya daxil olub: 27.05.2015

Çapa tövsiya olunub: 22.06.2015

Rəyçi: t.ü.f.d. Oliyev R.R. 